2019-06

\title{
Assessing methodologies for fucoidan extraction from South African brown algae
}

\author{
January, Grant
}

http://hdl.handle.net/10026.1/17448

10.1016/j.algal.2019.101517

Algal Research

Elsevier BV

All content in PEARL is protected by copyright law. Author manuscripts are made available in accordance with publisher policies. Please cite only the published version using the details provided on the item record or document. In the absence of an open licence (e.g. Creative Commons), permissions for further reuse of content should be sought from the publisher or author. 
Corrigendum

\title{
Corrigendum to "Assessing methodologies for fucoidan extraction from South African brown algae" [Algal Res. Volume 40 (June 2019) p101517]
}

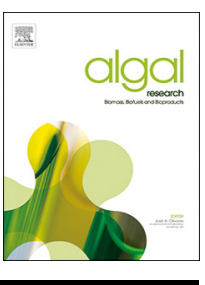

\author{
G.G. January ${ }^{\mathrm{a}, \mathrm{c}, *}$, R.K. Naidoo ${ }^{\mathrm{b}}$, B. Kirby-McCullough ${ }^{\mathrm{c}}$, R. Bauer ${ }^{\mathrm{d}}$ \\ ${ }^{a}$ Algal Research Group, Department of Biotechnology, Faculty of Natural Sciences, University of the Western Cape, Cape Town, South Africa \\ ${ }^{\mathrm{b}}$ Institute for Wine Biotechnology, Department of Viticulture and Oenology, Faculty of AgriSciences, Stellenbosch University, Stellenbosch, South Africa \\ ${ }^{\mathrm{c}}$ Institute for Microbial Biotechnology and Metagenomics, Department of Biotechnology, Faculty of Natural Sciences, University of the Western Cape, Cape Town, South \\ Africa \\ ${ }^{\mathrm{d}}$ Launch Lab, Stellenbosch University, Stellenbosch, South Africa
}

The authors regret the following line: "The South African coastline is characterized by high biodiversity [17] which has been largely untapped, primarily because of the large number of pristine marine protected areas (MPA)." The authors would like to replace this with the following sentence: "The South African coastline is characterized by high biodiversity [17] which has been largely untapped."

The authors would like to apologise for any inconvenience caused.

DOI of original article: https://doi.org/10.1016/j.algal.2019.101517

* Corresponding author at: Institute of Protein Biochemistry (IBP-CNR), National Research Council of Italy, Via Pietro Castellino 111, 80131 Naples, NA, Italy. E-mail address: grantgarrenjanuary@gmail.com (G.G. January). 